\title{
КВАЛИТЕТ НА ЖИВОТ: ЛИЦА СО ИНВАЛИДНОСТ И ЛИЦА БЕЗ ИНВАЛИДНОСТ
}

\section{Кратка содржина}

Квалитетот на животот се однесува на човечките вредности, односно среќ, задоволство, општо чувство на благосостојба и можноста за остваруваюе на сопствените потениијали. Тој е мултидимензионален феномен составен од основни области кои се под влијание на личните карактеристики и животната средина.

Целта на овој труд е да се утврди дали постои разлика помеѓу квалитетот на живот на лииата со инвалидност и без инвалидност во Република Македонија. Во истражувањето беа вклучени 136 лиияа без инвалидност и 60 лича со инвалидност. За мерење на квалитетот на животот е користена кратката верзија на прашалникот за квалитет на животот на СЗО. Резултатите покажаа дека лицата со инвалидност кои учествуваа во ова истражување субјективно имаат помал квалитет на живот од личата без инвалидност. Односно, личата со инвалидност имаа статистички послаби резултати во областите психичко здравје ( $p=0.0001)$, сочијални односи $(p=0.0002)$ и животна средина $(p=0.0002)$.

Клучни зборови: КВАЛИТЕТ НА ЖИВОТ, ПРОЦЕНА, ЛИЦА СО ИНВАЛИДНОСТ, ЛИЦА БЕЗ ИНВАЛИДНОСТ

\section{Вовед}

Глобално, во последните 30 години значително се променил ставот на општеството кон лицата со инвалидност, односно се донесоа и прифатија голем број конвенции за правата на лицата со инвалидност. Правата, сепак, не се доволни ако не постојат услови за нивно користење (Buntinx \& Schalock, 2010). Според Конвенцијата за правата на лицата со инвалидност (OH, 2006), лицата со инвалидност сѐ уште се соочуваат со бариери за рамноправно учество во општеството. Лицата со инвалидност имаат право на пристап и услуги кои ќе им овозможат квалитетен живот, ист како и на лицата без инвалидност (Townsend-White, 2012).

Квалитетот на животот е поврзан со човечките вредности, односно среќа, задоволство, општо чувство на благосостојба и можност за остварување на сопствените потенцијали (Cummins, 1991; Schalock, 2000; Brown \& Brown, 2009). Toj е мултидимензионален феномен составен од основни области кои се под влијание на личните карактеристики и животната средина (Verdugo et al., 2005). Постои меѓународен консензус за осумте области кои го дефинираат квалитетот на живот на 
индивидуата (Schalock et al., 2002; Brown \& Brown, 2009). Овие осум области се идентификувани и потврдени во низа крос-културни студии, тие се: емоционална благосостојба, меѓучовечки односи, материјална благосостојба, личен развој, физичка благосостојба, самоопределување, права и социјална инклузија (Schalock, 2000; Beadle-Brown et al., 2009; Wang et al., 2010). За лицата со инвалидност, најважните области на квалитетот на животот, како што е наведено во литературата, се: физичко здравје, психолошка благосостојба, семејна и социјална поддршка, физичка средина и заштита на животната средина (Murphy, 2007).

Квалитетот на животот, во последните години, сѐ повеќе се користи за да се утврди субјективната перцепција на личноста со инвалидност. Искуствата на две лица со ист степен на инвалидност може да се разликува во зависност од социјалната поддршка, условите за живот, па дури и од очекувањата од животот (Mattevi et al., 2012). Постојат многу инструменти за процена на квалитетот на животот. Но, не постои универзално прифатен идеален инструмент за процена на возрасните лица со различна инвалидност.

Голем број автори истакнуваат дека лицата со инвалидност и лицата без инвалидност исто го вреднуваат својот квалитет на живот (Schalock et al., 1996; Felce, 1995). Целта на овој труд е да се утврди дали постои разлика помеѓу квалитетот на животот на лицата со инвалидност и лицата без инвалидност во нашата држава.

\section{Методологија}

Примерок

Во истражувањето беа анкетирани 196 лица на возраст од 26 до 82 години од три општини: Куманово, Прилеп и Кочани. Од вкупниот број испитаници, 136 $(69.4 \%)$ се лица без инвалидност и $60(30,6 \%)$ лица со инвалидност. 25 лица се со оштетен вид, исто толку се лица со оштетен слух, и 10 лица со телесна инвалидност.

Инструмент

Користена е кратка верзија на прашалникот за квалитет на животот на C3O (WHOQOL-Bref, 2004). Оваа верзија се состои од 26 прашања, групирани во 4 области: физичко здравје (7 прашања), психичко здравје (6 прашања), социјални односи (3 прашања), животна средина (8 прашања) и две посебни прашања за целокупниот квалитет на животот и општата здравствена состојба. Од испитаниците се бараше да одговорат какви се нивните размислувања, односно способности да реализираат одредени работи во последните четири недели. Одговорите се нотираат на 5-степена Ликертова скала, при што повисокиот скор индицира подобар квалитет на животот.

\section{Статистика}

Податоците беа анализирани со употреба на софтверскиот пакет SPSS 14.0. За да направиме компарација и да го утврдиме односот помеѓу добиените податоци од различните групи испитаници, користени беа независно примерочен 
Т-тест и Пирсоновиот тест за корелација, на ниво на значајност од $\mathrm{p}<0,05$ и $\mathrm{p}<0,01$.

\section{Резултати и дискусија}

Анализата на резултатите покажаа дека во однос на полот не постои статистичка значајна разлика помеѓу групата лица со инвалидност и групата лица без инвалидност. Во однос на образованието, статистички поголем број од испитаниците без инвалидност се со основно образование, а од лицата со инвалидност се со средно образование. Исто така, констатирана е и статистичка значајна разлика помеѓу овие две групи испитаници ( $\mathrm{p}=0.003)$. Според другите демографски податоци, повеќето од испитаниците од двете групи се во брак и живеат со просечни примања. Демографските податоци се презентирани на Табела 1.

Табела 1. Демографски податоци на испитаници со инвалидност и испитаници без инвалидност

\begin{tabular}{|c|c|c|c|}
\hline Карактеристики & $\begin{array}{c}\text { Лица без } \\
\text { инвалидност } \\
(\mathrm{n}=136) \\
\end{array}$ & $\begin{array}{c}\text { Лица со } \\
\text { инвалидност }(\mathrm{n}=60)\end{array}$ & $\begin{array}{c}\text { Компарација помеѓу } \\
\text { групите }\end{array}$ \\
\hline \multicolumn{4}{|l|}{ Пол n (\%) } \\
\hline Машки & $57(41.9)$ & $28(46.7)$ & $X^{2}=0.383$ \\
\hline \multirow{2}{*}{ женски } & $79(58.1)$ & $32(53.3)$ & $\mathrm{df}=1, \mathrm{p}=0.5359$ \\
\hline & $X^{2}=3.559, \mathrm{p}=0.0592$ & $X^{2}=0.267, p=0.6056$ & \\
\hline \multicolumn{4}{|l|}{ Образование n (\%) } \\
\hline основно & $73(53.7)$ & $22(36.7)$ & $X^{2}=11.2577$ \\
\hline средно & $48(35.3)$ & $36(60)$ & $\mathrm{df}=2, \mathrm{p}=0.003$ \\
\hline \multirow[t]{2}{*}{ високо } & $15(11)$ & $2(33.3)$ & \\
\hline & $\begin{aligned} X^{2} & =37.455 \\
p & =0.0001\end{aligned}$ & $\begin{aligned} X^{2} & =29.200 \\
\mathrm{p} & =0.0001\end{aligned}$ & \\
\hline \multicolumn{4}{|l|}{ Брач. статус n (\%) } \\
\hline во брак & $99(72.8)$ & $36(60)$ & $X^{2}=3.6111$ \\
\hline самец & $32(23.5)$ & $22(36.7)$ & $\mathrm{df}=2, \mathrm{p}=0.1643$ \\
\hline \multirow[t]{2}{*}{ вдовец/ца } & $5(3.7)$ & $2(3.3)$ & \\
\hline & $\begin{array}{c}X^{2}=103.356 \\
\mathrm{p}=0.0001\end{array}$ & $\begin{aligned} X^{2} & =29.200 \\
\mathrm{p} & =0.0001\end{aligned}$ & \\
\hline \multirow{5}{*}{$\begin{array}{l}\text { Жив. станд. n (\%) } \\
\text { потпросечен } \\
\text { просечен } \\
\text { натпросечен }\end{array}$} & & & \\
\hline & $12(8.8)$ & $11(18.3)$ & $X^{2}=4.3119$ \\
\hline & $118(86.8)$ & $48(80)$ & $d f=2, p=0.1157$ \\
\hline & $6(4.4)$ & $1(1.7)$ & \\
\hline & $\begin{aligned} X^{2} & =61.300 \\
p & =0.0001\end{aligned}$ & $\begin{array}{c}X^{2}=175.140 \\
\mathrm{p}=0.0001\end{array}$ & \\
\hline
\end{tabular}

Од Табела 2 може да се констатира дека во однос на четирите области од WHOQOL-Bref прашалникот за квалитет на животот, кај испитаниците со инва- 
лидност и испитаниците без инвалидност е констатирана статистички значајна разлика во три области и тоа во областа на психичкото здравје $(\mathrm{p}=0.001)$, социјалните односи $(\mathrm{p}=0.002)$ и животната средина $(\mathrm{p}=0.001)$. Што се однесува до областа на физичкото здравје, во нашето истражување не е пронајдена статистички значајна разлика меѓу испитаниците ( $\mathrm{p}=0.6182)$.

Табела 2. Средна вредност на четирите области од WHOQOL-Bref

\begin{tabular}{|c|c|c|c|c|c|c|c|}
\hline \multirow[t]{2}{*}{ Области } & \multicolumn{2}{|c|}{$\begin{array}{c}\text { Лица без } \\
\text { инвалидност } \\
(n=136)\end{array}$} & \multicolumn{2}{|c|}{$\begin{array}{c}\text { Лица со } \\
\text { инвалидност } \\
(\mathrm{n}=60)\end{array}$} & \multirow[t]{2}{*}{$\mathrm{t}$} & \multirow[t]{2}{*}{ df } & \multirow[t]{2}{*}{$\mathrm{p}$} \\
\hline & $\mathrm{CB}$ & Сд & $\mathrm{CB}$ & СД & & & \\
\hline Физичко здравје & 3.221 & 1.001 & 3.298 & 0.982 & 0.499 & 194 & 0.6182 \\
\hline Психичко здравје & 4.017 & 0.965 & 3.363 & 0.944 & 4.4018 & 194 & 0.0001 \\
\hline Социјални односи & 3.810 & 0.933 & 3.255 & 0.921 & 3.8532 & 194 & 0.0002 \\
\hline Животна средина & 3.699 & 1.094 & 2.894 & 1.018 & 4.8477 & 194 & 0.0002 \\
\hline
\end{tabular}

Исто така, може да се заклучи дека обете групи испитаници дале највисоки бодови во областа на психичкото здравје $(\mathrm{CB}=4.017$ за лицата без инвалидност и $\mathrm{CB}=3.363$ за лицата со инвалидност), а последно рангирана област за лицата без инвалидност е областа на физичкото здравје $(\mathrm{CB}=3.221)$, додека за лицата со инвалидност е животната средина $(\mathrm{CB}=2.894)$. Ова може да се види на Слика 1.

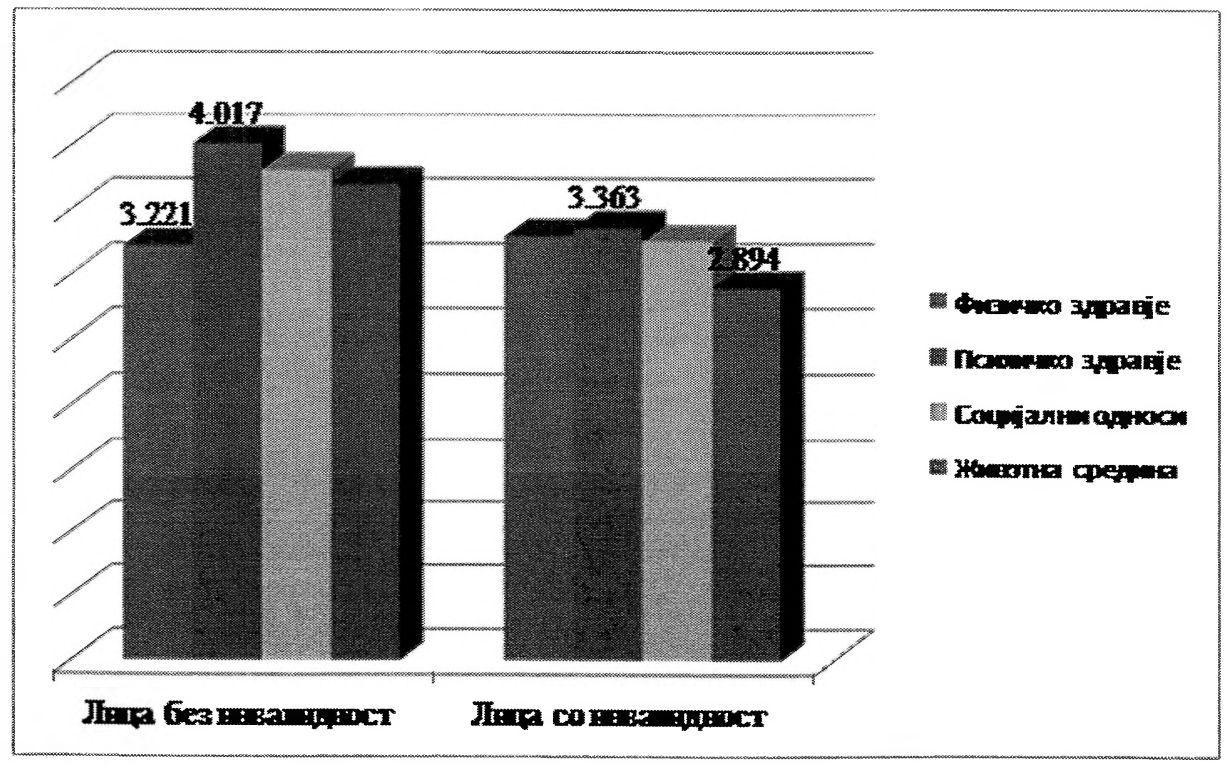

Слика 1. Постигнувања во областите од WHOQOL-Bref прашалникот (CB) 
Во Табела 3 ја анализиравме процената на квалитет на животот кај лицата со инвалидност и лицата без инвалидност на секое прашање од WHOQOL-Bref прашалникот според четирите области. Во областа на физичкото здравје, иако не е пронајдена статистички значајна разлика, добиени се интересни резултати. Имено, лицата без инвалидност изразиле поголема зависност од медицински третман $(\mathrm{CB}=1.830)$ и доживеале поголема физичка болка $(\mathrm{CB}=1.897)$ од лицата со инвалидност. Ваквата состојба сметаме дека се должи на субјективноста при оценувањето од страна на лицата без инвалидност, бидејќ објективно и непристрасно би требало лицата со инвалидност да изразат поголемо незадоволство на овие прашања. Во однос на подрачјето психичко здравје, од средната вредност на секое прашање може да констатираме дека кај лицата без инвалидност преовладуваат позитивни чувства $(\mathrm{CB}=3.845)$, задоволството од самите себе $(\mathrm{CB}=4.352)$ и физичкиот изглед $(\mathrm{CB}=4.426)$, за разлика од лицата со инвалидност кај кои не постои издиференцираност помеѓу позитивните $(\mathrm{CB}=3.1)$ и негативните чувства $(\mathrm{CB}=3.166)$ и кај кои е загубена смислата на животот $(\mathrm{CB}=3.15)$. Според добиената средна вредност на одговорите на прашањата од подрачјето сочијални односи, може да заклучиме дека лицата со инвалидност се незадоволни од квалитетот на нивниот сексуален живот ( $\mathrm{CB}=2.716)$, потоа следуваат личните контакти, а најзадоволни се од поддршката што им ја даваат пријателите $(\mathrm{CB}=3.683)$. Оваа поддршка е многу поголема од онаа што лицата без инвалидност мислат дека ја добиваат од своите пријатели $(\mathrm{CB}=3.602)$. Во областа животна средина можеме да заклучиме дека обете групи испитаници дале највисоки бодови и изразиле најголемо задоволство на прашањето кое се однесува на домашните услови за живот (CB=4.044 за лицата без инвалидност и $\mathrm{CB}=3.4$ за лицата со инвалидност), а најголемо незадоволство и последно рангирано прашање за обете групи испитаници е прашањето на задоволство од финансиските средства со кои располагаат.

Табела 3. Средна вредност на секое прашање од WHOQOL-Bref

\begin{tabular}{lcc}
\hline \multirow{2}{*}{ Прашања (ІІ) } & $\begin{array}{c}\text { Лица без инвалидност } \\
(\mathrm{n}=136)\end{array}$ & $\begin{array}{c}\text { Лица со инвалидност } \\
(\mathrm{n}=60)\end{array}$ \\
\cline { 2 - 3 } & СВ (СД) & СВ (СД) \\
\hline П1. Општ квалитет на животот & $4.286(0.815)$ & $3.333(0.968)$ \\
П2. Општо здравје & $4.213(0.829)$ & $3.283(0.940)$ \\
$\quad$ & & \\
$\quad$ Физичко здравје & $1.897(1.200)$ & $2.783(1.009)$ \\
П3. Болка & $1.830(1.064)$ & $2.633(0.919)$ \\
П4. Зависност од медиц. третман & $3.823(0.965)$ & $3.333(0.968)$ \\
П10. Енергија & $4.213(0.792)$ & $3.4(0.847)$ \\
П15. Мобилност & $3.507(1.047)$ & $3.366(1.040)$ \\
П16. Сон & $3.544(1.017)$ & $3.416(0.829)$ \\
П17. Секојдневни активности & $4.272(0.793)$ & $3.616(1.009)$ \\
П18. Работен капацитет & & \\
$\quad$ Психичко здравје & $3.845(1.108)$ & $3.1(0.933)$ \\
П5. Позитивни чувства & $4.044(0.824)$ & $3.15(0.860)$ \\
П6. Смисла на животот & &
\end{tabular}




\begin{tabular}{lcc} 
П7. Концентрација & $3.963(0.922)$ & $3.233(0.721)$ \\
П11. Физички изглед & $4.426(0.785)$ & $3.883(1.151)$ \\
П19. Задоволни од себе & $4.352(0.745)$ & $3.65(0.988)$ \\
П26. Негативни чувства & $3.477(1.141)$ & $3.166(1.011)$ \\
$\quad$ Социјални односи & & \\
П20. Лични контакти & $3.904(0.833)$ & $3.366(0.882)$ \\
П21. Сексуален живот & $3.926(0.883$ & $2.716(1.009)$ \\
П22. Поддршка од пријателите & $3.602(1.034)$ & $3.683(0.873)$ \\
$\quad$ Животна средина & & \\
П8. Физичка безбедност & $3.919(1.115)$ & $2.566(1.125)$ \\
П9. Здрава средина & $3.727(1.238)$ & $2.638(1.157)$ \\
П12. Финансиски средства & $3.014(1.060)$ & $2.533(0.964)$ \\
П13. Достапност на информации & $3.823(0.941)$ & $2.766(0.810)$ \\
П14. Слободни активности & $3.919(1.004)$ & $2.95(1.015)$ \\
П23. Домашни услови & $4.044(0.884)$ & $3.4(0.847)$ \\
П24. Здравствени услуги & $3.639(1.325)$ & $3.016(1.081)$ \\
П25. Транспорт & $3.507(1.192)$ & $3.283(1.151)$ \\
\hline
\end{tabular}

\section{Заклучок}

Поимот квалитет на животот е тешко да се дефинира поради бројните и сложени компоненти кои ги вклучува. Разни автори го интерпретираат на различни начини, но, главно, сите се согласни дека тој е мултидимензионален концепт кој едновремено опфаќа значаен број објективни и субјективни фактори и е под влијание на разните индивидуални и средински фактори, како и нивните меѓусебни релации.

Квалитетот на животот за лицата со инвалидност во основа е одреден од истите или слични индикатори како и во општата популација, но постојат специфични обележја кои се поврзани со карактеристиките на развој на овие лица и нивната положба во општеството и интеракцијата со средината (Костиќ-Ивановиќ, 2013). Резултатите покажуваат дека лицата со инвалидност кои учествуваа во нашето истражување субјективно имаат помал квалитет на живот од лицата без инвалидност. Поради тоа, потребно е подигање на општествената свест за потребите и проблемите на лицата со инвалидност, преку развој на сервиси за помош и поддршка на овие лица и нивна подобра интеграција во општествената средина. 


\section{Литература}

Beadle-Brown, J., Murphy, G. \& diTerlizzi, M. (2009). Quality of life for the Camberwell Cohort. Journal of Applied Research in Intellectual Disabilities, 22, 380-90.

Brown, I. \& Brown, R. I. (2009). Choice as an aspect of quality of life for people with intellectual disabilities. Journal of Policy and Practice in Intellectual Disabilities, 6, 11-18.

Buntinx, W. H. E. \& Schalock, R. L. (2012). Models of Disability, Quality of Life, and Individualized Supports: Implications for Professional Practice in Intellectual Disability. Journal of Policy and Practice in Intellectual Disabilities, 7(4), 283-94.

Cummins, R. A. (1991). The Comprehensive Quality of Life Scale-Intellectual Disability: an instrument under development. Australia \& New Zealand Journal of Developmental Disabilities, 17, 259-64.

Felce, D. \& Perry, J. (1995) Quality of life: its definition and measurement. Res Dev Disabil., 16, 51-74.

Костиќ-Ивановиќ, В. (2013). Квалитет на живот кај возрасни лица со интелектуална попреченост од различни животни услови (докторска дисертација). Скопје: Филозофски факултет.

Mattevi, B.S., Bredemeier, J., Fam, C., \& Fleck, M.P. (2012). Quality of care, quality of life, and attitudes toward disabilities: perspectives from a qualitative focus group study in Porto Alegre, Brazil. Rev Panam Salud Public, 31(3), 188-96.

Murphy, K., O'Shea, E., Cooney, A., \& Casey, D. (2007). The Quality of Life of Older People With a Disability in Ireland. Galway: National University of Ireland.

Schalock, R. L. (1996). Reconsidering the conceptualization and measurement of quality of life. In R. L. Schalock (Ed.), Quality of life. Volume I: Conceptualization and measurement (pp. 123-39). Washington, DC: American Association on Mental Retardation.

Schalock, R. L. (2000) Three decades of quality of life. In M. L. Wehm-eyer \& J. R. Patton (Ed.), Mental Retardation in the 21st Century (pp. 335-56). Pro-ed, Austin, TX.

Schalock R. L., Brown, I., Cummings, R. A., Felce, D., Matikka L., Keith K. D. et al. (2002). Conceptualization, measurement, and application of quality of life for persons with intellectual disabilities: report of an international panel of experts. Mental Retardation, 40, 457-70.

The World Health Organization Quality of Life (WHOQOL)-BREF (2004). Available at: http://www.who.int/substance_abuse/research_tools/en/english_whoqol.pdf

Townsend-White, C., Pham, A. N.T\& Vassos, M. V. (2012). A systematic review of quality of life measures for people with intellectual disabilities and challenging behaviours. Journal of Intellectual Disability Research, 56(3), 270-284. doi: 10.1111/j.1365-2788.2011.01427.x 
United Nations (2006) Convention on the rights of persons with disabilities. Available at: http://www.un.org/disabilities/convention/conventionfull.shtml

Verdugo, M. A., Schalock, R. L., Keith, K. D. \& Stancliffe, R. J. (2005). Quality of life and its measurement: important principles and guidelines. Journal of Intellectual Disability Research, 49, 707-17.

Wang, M., Schalock, R. L., Verdugo, M. A. \& Jenaro, C. (2010). Examining the factor structure and hierarchical nature of the quality of life construct. American Journal on Intellectual and Developmental Disabilities 115, 218-33. 
Daniela DIMITROVA-RADOJICHIKJ

Natasha CHICHEVSKA-JOVANOVA

\section{QUALITY OF LIFE OF THE PERSONS WITH AND WITHOUT DISABILITIES}

\section{Summary}

Quality of life ( $Q O L)$ is associated with human values including happiness, satisfaction, general feelings of well-being and opportunities to achieve personal potential. It is a multidimensional phenomenon composed of core domains and elements that are influenced by personal characteristics and environmental.

The aim of this paper is to determine whether there is a difference between the Quality of life of people with and without disability in the Republic of Macedonia. A total of 136 people without disability and 60 people with disability were included in the study. The World Health Organization's Quality of Life Questionnaire (WHOQoL$B R E F)$ was used to measure the quality of life. The results showed that the persons with disabilities, included in our study, subjectively have had lower quality of life than the persons without disabilities. Namely, people with disability had statistically lower scores in the psychological domain $(p=0.0001)$, social relationship domain $(p=0.0002)$ and environmental domain ( $p=0.0002)$ compared to people without disability.

Keywords: QUALITY OF LIFE, MEASUREMENT, PEOPLE WITH DISABILITY, PEOPLE WITHOUT DISABILITY 